\title{
Penguatan Pendidikan Karakter di Pondok Pesantren Darul Ulum Kabupaten Kubu Raya
}

\author{
Muhamad Tisna Nugraha ${ }^{1}$, Andewi Suhartini ${ }^{2}$, Nurwadjah Ahmad EQ ${ }^{3}$, Anwar ${ }^{4}$ \\ ${ }^{1}$ Institut Agama Islam Negeri (IAIN) Pontianak, Indonesia \\ ${ }^{2}$ Universitas Islam Negeri (UIN) Sunan Gunung Djati Bandung, Indonesia \\ ${ }^{3}$ Universitas Islam Negeri (UIN) Sunan Gunung Djati Bandung, Indonesia \\ ${ }^{4}$ Sekolah Tinggi Ilmu Tarbiyah Darul Ulum (STITDAR) Kubu Raya, Indonesia
}

\begin{tabular}{l} 
INFO ARTIKEL \\
\hline Riwayat Artikel: \\
Diterima: $05-11-2020$ \\
Disetujui: $31-12-2020$ \\
Diterbitkan: $31-12-2020$
\end{tabular}

\section{Kata kunci:}

Pendidikan Karakter

Pesantren Khalaf

\author{
Alamat Korespondensi: \\ Muhamad Tisna Nugraha \\ Program Studi Pendidikan Guru Madrasah Ibtidaiyah (PGMI) \\ Institut Agama Islam Negeri (IAIN) Pontianak \\ E-mail: tisnanugraha2014@yahoo.com
}

ABSTRAK

Abstract: This study aims to describe the values of character education in khalaf Pesantren. Beside that, this study also explains the implementation of the education character that applies in khalaf Pesantren. The method used in this research is a qualitative method with a research design in the form of library research. Meanwhile, the research instruments used to data collection is documentation and observation. Based on the results of the research, it shows that the character developed in khalaf pesantren consists of 18 character values, including: 1) religious, 2) honest, 3) tolerance, 4) discipline, 5) hard work, 6) creative, 7) independent, 8) democratic, 9) curiosity, 10) spirit of togetherness, 11) love for the country, 12) respect for achievement, 13) friendly or communicative, 14) love peace, 15) love to read, 16) care for the environment, 17 ) social care, and 18) responsibility. Other than that, implementation through in process of recitation and the pesantren culture. In addition, character education at the khalaf pesantren is carried out through a process of learning and self-development both contained in intra-curricular, co-curricular and extracurricular activities.

Abstrak: Penelitian ini bertujuan untuk mendeskripsikan nilai-nilai pendidikan karakter yang terdapat pada pesantren khalaf. Selain itu, penelitian ini juga menjelaskan pelaksanaan pendidikan karakter yang berlaku di pondok pesantren khalaf. Adapun metode yang digunakan dalam penelitian ini adalah metode kualitatif dengan desain penelitiannya berupa studi kepustakaan (library research). Sedangkan untuk instrumen penelitian yang digunakan dalam pengumpulan datanya adalah berupa dokumentasi dan observasi. Berdasarkan hasil penelitian menunjukkan bahwa karakter yang dikembangkan di pondok pesantren khalaf terdiri atas 18 nilai-nilai karakter, antara lain:1) religius, 2) jujur, 3) toleransi, 4) disiplin, 5) kerja keras, 6) kreatif, 7) mandiri, 8) demokratis, 9) rasa ingin tahu, 10) semangat kebersamaan, 11) cinta tanah air, 12) menghargai prestasi, 13) bersahabat atau komunikatif, 14) cinta damai, 15) gemar membaca, 16) peduli lingkungan, 17) peduli sosial, dan 18) tanggungjawab. Sedangkan untuk pelaksanaannya dilakukan melalui proses pengajian dan kultur budaya pesantren Selain itu, pendidikan karakter di pondok pesantren khalaf dilakukan melalui proses pembelajaran dan pengembangan diri baik yang terdapat dalam kegiatan intrakurikuler, kokurikuler dan ekstrakurikuler.

\section{LATAR BELAKANG}

Krisis multidimensional yang terjadi dalam beberapa dekade terakhir, telah menghadirkan kecemasan akan ketidaksiapan generasi penerus bangsa dalam memimpin serta menghadapi berbagai tantangan global. Sejumlah pemberitaan di media cetak dan elektronik mengenai tindakan kriminal 
yang dilakukan anak-anak dan remaja, menjadi indikasi bahwa pendidikan yang dilaksanakan belum dapat menjawab pelbagai tantangan perkembangan zaman. Padahal Allah Subhanahu Wa Ta'ala telah mengingatkan dalam firman-Nya dalam surah An-Nisa (4): 9.

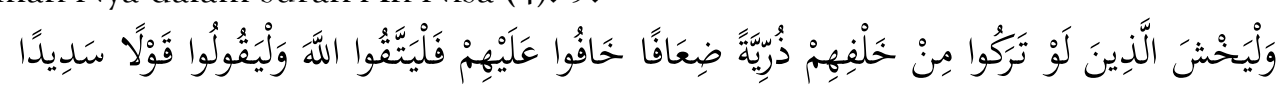

Artinya: "Dan hendaklah takut kepada Allah orang-orang yang seandainya meninggalkan di belakang mereka anak-anak yang lemah, yang mereka khawatir terhadap (kesejahteraan) mereka. Oleh sebab itu hendaklah mereka bertakwa kepada Allah dan hendaklah mereka mengucapkan perkataan yang benar".

Dari terjemahan ayat tersebut, maka sudah sepantasnya bagi umat Islam, khususnya para orangtua untuk tidak lengah dalam hal membekali atau mempersiapkan anak-anak Muslim, baik yatim, yatim-piatu maupun keturunannya dengan segenap kemampuan yang ada, sehingga generasi-generasi yang kelak akan ditinggalkan dan dipercaya memegang amanah dapat melaksanakan tugas dan fungsinya sesuai dengan harapan. Degradasi moral yang terjadi pada anak dan remaja dipercaya merupakan puncak krisis akhlak yang terjadi akibat rusaknya dimensi moral dengan mentalitas. Kemiskinan, lemahnya pengawasan orangtua, lingkungan yang tidak kondusif, hingga kebodohan akibat tidak memperoleh pendidikan. Pada akhirnya menyebabkan anak-anak dan remaja menghalalkan segala hal untuk memenuhi kebutuhannya. Untuk itu, internalisasi pendidikan karakter dalam kurikulum yang diberlakukan diharapkan dapat menjawab dinamika persoalan yang terjadi. Mengingat kurikulum dan pembelajaran dan materi agama terutama di sekolah-sekolah umum masih belum mendapatkan porsi yang seimbang. Terlebih tujuan pembelajaran yang ada masih mengedepankan materi ilmu pengetahuan dan belum menyentuh aspek spiritual dan moral. Padahal moralitas semacam itulah yang dapat berfungsi sebagai mekanisme kontrol sosial untuk menangkal terjadinya berbagai praktek amoral dalam kehidupan politik dan ekonomi, seperti yang merajalela sampai sekarang (Rusydi Syahara, 2001). Hal ini sejalan dengan pendapat Muhmad Tisna Nugraha (2015) yang menyebutkan bahwa pendidikan harus mampu mengemban misi pembentukan kultur akhlak mulia (character building) sehingga peserta didik dan lulusanya dapat berpartisipasi dalam mengisi pembangunan di masa mendatang tanpa mengenyampingkan nilai-nilai moral atau akhlak mulia (alakhlaq al-karimah).

Dari sejumlah lembaga pendidikan yang ada dan berkembang saat ini, pesantren merupakan salah satu lembaga pendidikan Islam tertua yang ada di Indonesia. Lembaga ini telah memberikan kontribusi terhadap kehidupan sosial-keagamaan dan kenegaraan, serta menjadi benteng dalam mempertahankan nilai-nilai luhur ajaran Islam di tengah pelbagai krisis multidimensional. Dalam konteks ini suatu pesantren yang ideal menurut Abdul Basyit (2017) adalah pesantren yang mampu berdialog dengan modernitas tanpa harus mengeliminasi tujuan utamanya sebagai pengemban amanat moral.Untuk itu, sudah sepatutnya implementasi pendidikan karakter yang ada di pesantren dapat menjadi panutan (role model) dalam penanaman nilai-nilai karakter bangsa. Sebagai salah satu pesantren tertua dan terbesar di Kabupaten Kubu Raya, pesantren Darul Ulum menjadi salah lembaga pendidikan Islam yang turut diperhitungkan keberadaannya. Pesantren ini tidak hanya mampu menyelenggarakan pendidikan di tingkat dasar, melainkan juga hingga tingkat Perguruan Tinggi Keagamaan Islam (PTKI). Selain itu, Kalimantan Barat sebagai salah satu provinsi di Indonesia yang secara geografis berbatasan langsung dengan Serawak, Malaysia. Hal ini tentunya menjadi dasar pertimbangan dalam menyusun kebijakan strategis di bidang hubungan internasional terutama di bidang pendidikan berbasis pesantren.

Dari paparan penjelasan yang telah dikemukakan pada bagian pendahuluan, maka peneliti kemudian tertarik untuk mengkaji lebih lanjut tentang pelaksanaan penguatan pendidikan karakter yang dilakukan di pondok pesantren Darul Ulum Kabupaten Kubu Raya, Kalimantan Barat.

\section{METODE}

Penelitian ini menggunakan pendekatan penelitian lapangan (field research) dengan metode kualitatif. Hal ini dilakukan oleh peneliti untuk menemukan dan mengungkap implementasi 
Penguatan Pendidikan Karakter yang ada di pondok pesantren Darul Ulum dan nilai-nilai karakter yang ditanamkan di dalamnya. Adapun instrumen yang digunakan dalam penelitian ini dilakukan dengan teknik observasi, wawancara, dan dokumentasi. Sedangkan untuk analisis datanyanya peneliti menggunakan analisis deskriftif kualitatif, hal ini karena analisis tersebut dianggap tepat untuk mengungkap dan mengidentifikasi ciri-ciri khas pendidikan karakter dan kultur pesantren yang ada di pondok pesantren tersebut.

\section{HASIL DAN PEMBAHASAN}

\section{Pesantren Khalaf dan Pendidikan Karakter}

Zarkasyi (Krisdiyanto, et al., 2019) mendefinisikan pesantren sebagai sebuah lembaga pendidikan Islam dengan sistem asrama atau pondok, dimana kiyai atau ajengan menjadi sosok sentralnya, masjid sebagai pusat kegiatan yang menjiwainya, dan pengajaran Islam oleh kyai atau ajengan kepada santri sebagai kegiatan utamanya. Sedangkan menurut Mastuhu (Samsudin, 2019) pesantren didefinisikan sebagai lembaga pendidikan tradisional Islam untuk mempelajari, memahami, mendalami, menghayati, dan mengamalkan ajaran Islam dengan menekankan pentingnya moral keagamaan sebagai pedoman perilaku dalam kehidupan sehari-hari.

Definisi yuridis dari pesantren berdasarkan Undang-Undang Republik Indonesia Nomor 18 Tahun 2019 Tentang Pesantren, Pasal 1 ayat 1 menyatakan bahwa Pondok pesantren, Dayah, Surau, Meunasah, atau sebutan lain yang selanjutnya disebut pesantren adalah lembaga yang berbasis masyarakat dan didirikan oleh perseorangan, yayasan, organisasi masyarakat Islam, dan/atau masyarakat yang menamakan ketakwaan kepada Allah Subhanahu Wa Ta'ala menyemaikan akhlak mulia serta memegang teguh ajaran Islam rahmatan lil'alamin yang tercermin dari sikap rendah hati, toleran, keseimbangan, moderat, dan nilai luhur bangsa Indonesia lainnya melalui pendidikan, dakwah Islam, keteladanan, dan pemberdayaan masyarakat dalam kerangka negara kesatuan Republik Indonesia.

Adapun komponen-komponen yang terdapat dalam pesantren, menurut Achmad Zainal Huda (Nugraha, 2019) menyebutkan bahwa dalam pesantren ada lima elemen dasar yang menjadi tradisi pesantren, yaitu: (1) santri (murid yang belajar mengaji kepada kyai, (2) pondok (asrama bagi para santri), (3) masjid, (4) pengajaran kitab-kitab klasik, dan (5) kyai. Dari lima elemen dasar tersebut, masyarakat pesantren menganggap Kyai memegang peranan sentral dalam membentengi umat dari ancaman kekuatan-kekuatan jahat dari luar. Peranan kyai dalam menjaga tradisi keagamaan akhirnya membentuk subkultur pesantren, yaitu suatu gerakan sosial budaya yang dilakukan komunitas santri dengan karakter keagamaan dalam kurun waktu relatif panjang. Dengan demikian, Kyai adalah pengasuh para santri dan tauladan dari seluruh anggota masyarakat.

Selanjutnya jika ditinjau secara historis di awal perkembangannya, pesantren belum memiliki formulasi tujuan yang jelas baik dari tatanan institusional, kurikuler maupun instruksional umum dan khusus. Tujuan yang dimiliki di awal-awal perkembangannya semata-mata hanya mencetak ulama maupun memperdalam kajian ilmu agama (tafaqquh fiddin). Mastuhu (dalam mujamil Qomar, 2007) melaporkan bahwa tidak pernah dijumpai perumusan tujuan pendidikan pesantren yang jelas dan standar yang berlaku bagi semua pesantren. Pokok persoalan ini bukan terletak pada ketiadaan tujuan melainkan tidak tertulisnya tujuan tersebut. Selain itu, tujuan dari pendidikan Pesantren yang berbeda sesuai dengan otonomi dari masing-masing pesantren menyebabkan di masa awal kehadirannya belum ada kesamaan tujuan dari seluruh pesantren yang ada. Namun seiring dengan disahkannya UndangUndang Republik Indonesia Nomor 18 Tahun 2019 Tentang Pesantren, maka apa yang menjadi tujuan nasional dari penyelenggaraan pesantren, sebagaimana disebutkan dalam pasal 3 undang-undang tersebut adalah: a) membentuk individu yang unggul di berbagai bidang yang memahami dan mengamalkan nilai ajaran agamanya dan atau menjadi ahli ilmu agama yang beriman, bertakwa, berakhlak mulia, berilmu, mandiri, tolong-menolong, seimbang, dan moderat; b) membentuk pemahaman agama dan keberagamaan yang moderat dan cinta tanah air serta membentuk perilaku 
yang mendorong terciptanya kerukunan hidup beragama; dan c) meningkatkan kualitas hidup masyarakat yang berdaya dalam memenuhi kebutuhan pendidikan warga negara dan kesejahteraan sosial masyarakat.

Ditinjau dari tipologinya pesantren dapat dibagi menjadi tiga, yaitu pesantren salaf (tradisional), pesantren khalaf (modern) dan pesantren terpadu (campuran). Adapun penjelasan dari ketiga tipologi pesantren sebagaimana dimaksud adalah sebagai berikut:

Pesantren salafi adalah pesantren yang menggunakan kitab-kitab Islam klasik (kitab kuning) sebagai materi pendidikannya dan pendekatan tradisional (klasik) sebagai metode pembelajarannya Fauzan (2017: 604) menyatakan bahwa pesantren salafi masih memakai metode pembelajaran tradisional (klasik), seperti sorogan (individual) dan bandongan (kelompok). Selain itu, sistem perjenjangan santri pada pesantren salafi tidak didasarkan pada satuan waktu tertentu, melainkan didasarkan pada ketuntasan santri dalam mempelajari kitab tertentu, misalnya setelah menamatkan kitab al-Jurumiyah, santri baru dapat melanjutkan pelajaran ke kitab Alfiyah. Pesantren khalaf adalah pesantren yang dalam kegiatan pendidikannya telah menggunakan pendekatan dan sistem pendidikan modern. Hal ini sebagaimana dikemukakan Wahjoetomo (Khoiriyah, et al., 2017) yang menyatakan bahwa pesantren khalaf dicirikan dengan adanya adaptasi kurikulum pendidikan umum dalam kurikulum pendidikan yang biasa diajarkan di pesantren. Selain itu pada pesantren khalaf satuan pendidikan telah disusun secara berjenjang dengan memperhatikan satuan waktu tertentu melalui penyelenggaraan pendidikan formal seperti madrasah (MI, MTs, MA) maupun sekolah umum (SD, SMP, SMA). Pesantren terpadu (campuran) yaitu pesantren yang memadukan sistem pendidikan salaf dan khalaf. Dalam hal ini, kajiankajian kitab klasik pada pesantren terpadu tetap dilaksanakan sebagai sistem yang menjadi ciri khas pesantren, namun sistem pendidikan modern juga dilaksanakan dalam sistem pendidikannya. Fauzan (2017) menyebutkan bahwa biasanya pesantren semacam ini membagi waktu belajarnya ke dalam dua bagian yaitu pada siang hari aktivitas pendidikannya dilakukan dalam bentuk pendidikan formal, sedangkan pada malam harinya dengan sistem pendidikan pesantren dengan mempelajari kitab-kitab klasik.

Dari ketiga tipologi pesantren sebagaimana dijelaskan, maka penelitian ini secara lebih intensif diarahkan untuk mengkaji lebih lanjut tentang pesantren khalaf (modern), yakni pesantren yang berdasarkan pengelompokannya telah memasukan sistem pendidikan umum maupun madrasah di lingkungan pesantrennya. Selain itu, pesantren khalaf adalah pesantren yang dalam sistem kelembagaannya telah dikelola secara modern dengan sistem administrasi berbasis teknologi, serta sistem dan substansi pengajaran yang lebih menyesuaikan perkembangan zaman.

Selanjutnya yang dimaksud dengan pendidikan karakter menurut pendapat Sukiyat (2020) menyatakan bahwa pendidikan karakter adalah proses membentuk karakter, dimana karakter itu dibentuk oleh kebiasaan, dan kebiasaan atau hasil dari perbuatan yang dilakukan berulang-ulang sedangkan perbuatan adalah aksi dari sebuah gagasan. Sedangkan menurut Citra (2012) pendidikan karakter adalah suatu sistem penanaman nilai-nilai karakter kepada warga sekolah yang meliputi komponen pengetahuan, kesadaran atau kemauan, dan tindakan untuk melaksanakan nilai-nilai tersebut, baik terhadap Tuhan Yang Maha Esa (YME), diri sendiri, sesama, lingkungan, maupun kebangsaan sehingga menjadi manusia yang sempurna (insan kamil). Adapun yang dimaksud dengan Penguatan Pendidikan Karakter Peraturan Menteri Pendidikan dan Kebudayaan Republik Indonesia Nomor 20 Tahun 201 Tentang Penguatan Pendidikan Karakter Pada Satuan Pendidikan Formal. Berdasarkan Pasal 1 Ayat 1 Peraturan Menteri Pendidikan dan Kebudayaan Republik Indonesia Nomor 20 Tahun 2018 Tentang Penguatan Pendidikan Karakter Pada Satuan Pendidikan Formal, menyebutkan bahwa Penguatan Pendidikan Karakter yang selanjutnya disingkat PPK adalah gerakan pendidikan di bawah tanggung jawab satuan pendidikan untuk memperkuat karakter peserta didik melalui harmonisasi olah hati, olah rasa, olah pikir, dan olah raga dengan pelibatan dan kerja sama antara satuan pendidikan, keluarga, dan masyarakat sebagai bagian dari Gerakan Nasional Revolusi Mental (GNRM). 
Pelaksanaan Penguatan Pendidikan Karakter (PPK) dilakukan dengan tetap menerapkan nilai-nilai Pancasila, yang meliputi: nilai-nilai religius, jujur, toleran, disiplin, bekerja keras, kreatif, mandiri, demokratis, rasa ingin tahu, semangat kebangsaan, cinta tanah air, menghargai prestasi, komunikatif, cinta damai, gemar membaca, peduli lingkungan, peduli sosial, dan bertanggung jawab. Kedelapan belas nilai-nilai karakter sebagaimana dimaksud merupakan perwujudan dari 5 (lima) nilai utama yang saling berkaitan antara satu dengan yang lain, yaitu religiusitas, nasionalisme, kemandirian, gotong royong, dan integritas yang kemudian terintegrasi dalam kurikulum. Berkaitan dengan implementasi pendidikan karakter di pesantren, hal ini tidak secara mutlak bertentangan dengan pendidikan pesantren. Nashihi (2017) menyatakan bahwa pendidikan di pesantren justru dapat dijadikan sebagai rujukan mengenai pendidikan karakter yang seutuhnya, karena pendidikan di pesantren sangat mengedepankan akhlak atau karakter bagi santrinya. Selain itu, fakta sejarah telah membuktikan bahwa pesantren terbukti mampu mempertahankan eksistensinya dalam menghadapi perkembangan zaman. Bahkan pesantren semakinberkembang seiring dengan perkembangan masyarakat, dengan kata lain pesantren dapat dikatakan sebagai salah satu lembaga pendidikan yang sukses mengembangkan pendidikan karakter.

Berdasarkan beberapa definisi tentang pesantren serta kaitanya dengan pendidikan karakter, maka dapat disimpulkan bahwa pendidikan karakter di pesantren adalah upaya untuk menanamkan nilainilai karakter kepribadian bangsa melalui kultur atau budaya yang terdapat di pesantren, serta dibangun dan dikembangkan dalam rangka menjaga kesatuan dan persatuan negara Republik Indonesia.

\section{Pendidikan Karakter di Pondok Pesantren Darul Ulum}

Pondok Pesantren Darul Ulum didirikan pada tahun 1977 Masehi oleh K.H. Chairuman Ar Rahbini, yang dilatarbelakangi upaya untuk menciptakan masyarakat madani yang beriman, bertaqwa, berilmu, cerdas dan berakhlakul karimah di Kabupaten Kubu Raya. Darul Ulum merupakan ke-lanjutan dari Pondok Pesantren At-Taroqi yang ada di Desa Sungai Segak Kecamatan Sengah Temila, Kabupaten Landak. Namun dengan dasar pertimbangan Strategis untuk memberikan akses yang lebih luas kepada masyarakat, maka Pondok Pesantren At-Taroqi tersebut kemudian ditutup dan dipindahkan ke Desa Kuala Dua, Kecamatan Sungai Raya, serta diganti dengan nama Pondok Pesantren Darul-Ulum. Pembangunan dan pengembangan Pondok Pesantren Darul Ulum diawali dengan sebuah masjid dan asrama yang berfungsi sebagai tempat ibadah dan aktivitas belajar santri. Kemudian seiring dengan dukungan dari berbagai pihak yang berasal dari internal dan eksternal pesantren Darul-Ulum, kemudian berkembang dengan diikuti berdirinya lembaga-lembaga formal mulai dari tingkat TK, Madrasah Ibtidaiyah, Madrasah Tsanawiyah, Madrasah Aliyah hingga Sekolah Tinggi Ilmu Tarbiyah Darul Ulum (STITDAR).

Berdasarkan data yang diperoleh pada November 2020 jumlah tenaga pendidik yang ada di pesantren Darul Ulum adalah berjumlah 90 orang yang sebagian sebagian besar diantaranya merupakan alumni pondok pesantren. Selain itu, jumlah santriwan dan satriwai yang belajar di Pondok Pesantren Darul-Ulum berjumlah 1417 orang yang berasal dengan rincian TKIT Darul Ulum sebanyak 36 orang, Madrasah Ibtidaiyah sebanyak 335 orang, Madrasah Tsanawiyah sebanyak 260 orang. Madrasah Aliyah sebanyak 210 orang. Madrasah Diniyah Salafiyah sebanyak 415 orang dan Sekolah Tinggi Ilmu Tarbiyah Darul Ulum (STITDAR) sebanyak 161 orang. Pendidikan di pesantren Darul Ulum dilaksanakan dengan menerapkan kurikulum nasional dari Kementerian Agama (Kemenag) yang dasar pemberlakuannya pada tingkat madrasah mengacu pada Keputusan Menteri Agama Republik Indonesia Nomor 117 tahun 2014 tentang Implementasi Kurikulum 2013 di Madrasah, sedangkan untuk tingkat Perguruan Tingginya, saat ini Sekolah Tinggi Ilmu Tarbiyah Darul Ulum (STITDAR) merujuk pada Kerangka Kualifikasi Nasional Indonesia (KKNI) sebagaimana yang terdapat pada peraturan presiden Republik Indonesia nomor 8 tahun 2012 tentang Kerangka Kualifikasi Nasional Indonesia.

Selain kurikulum madrasah dan KKNI yang telah disebutkan, Darul Ulum juga memberlakukan kurikulum mandiri, berupa kurikulum pendidikan pesantren yang menjadi ciri khas dan kultur pesantren Darul Ulum. Kurikulum pesantren dapat lahir dari dinamika sosial, budaya, dan keagamaan 
masyarakat Islam tradisional yang dalam hal ini telah membentuk subkultur secara sosiologisantropologis bagi masyarakat pesantren. Kurikulum ini berupa kurikulum terselubung (hidden curriculum) maupun kurikulum dalam bentuk mata pelajaran yang mengkaji kitab-kitab kuning seperti safinatun najah, matan al-Jurumiyah, amtsilati, sirah nabawiyah, tagrib, imrithi, fathul qorib, fathul muin, dan lain-lain.

Penguatan pendidikan karakter yang dilaksanakan di pesantren Darul Ulum, dilaksanakan melalui kegiatan; a) intrakurikuler, b) kokulikuler dan c) ekstrakurikuler. Kegiatan intrakurikuler adalah kegiatan pembelajaran yang berlangsung di dalam kelas dalam rangka pemenuhan beban belajar yang terdapat dalam kurikulum nasional sesuai dengan ketentuan peraturan perundang-undangan. Dalam hal ini pendidikan karakter terintegrasi pada setiap materi pelajaran yang ditawarkan di madrasah yang ada di Darul Ulum sesuai dengan jenjang pendidikannya, serta tercermin di dalam kompetensi inti yang saling terkait, yakni berkaitan dengan sikap keagamaan atau kompetensi inti sikap spiritual (K-1), kompetensi inti sikap sosial (K-2), kompetensi inti pengetahuan (K-3), dan kompetensi inti penerapan pengetahuan atau keterampilan (K-4), dengan kata lain rumusan nilai-nilai karakter dapat dimiliki oleh peserta didik setelah mereka mengikuti proses pembelajaran di setiap pertemuan dan disesuaikan dengan kompetensi utama materi pembelajaran pada saat itu.

Untuk penguatan pendidikan karakter yang dilakukan pada kegiatan kokurikuler di pesantren Darul Ulum pada dasarnya merupakan kegiatan penguatan, pendalaman, dan/atau pengayaan dari kegiatan Intrakurikuler yang ada. Kegiatan kokurikuler dalam rangka penguatan pendidikan karakter dilakukan dalam bentuk Masa Pengenalan Lingkungan Madrasah (MPLM), outbound, study tour, bakti sosial, dan lain-lain. Sedangkan untuk kegiatan ekstrakurikuler atau berkaitan dengan kegiatan pengembangan potensi, bakat, minat, kemampuan, dan kemandirian peserta didik kegiatan ini dilakukan di bawah bimbingan guru, ustadz atau pelatih dalam bentuk kegiatan, seperti Tahfizdul Qur'an, khitobah, qasidah, Marchingband dan lain-lain.

Tidak hanya dalam kegiatan pendidikan formal yang berlangsung di dalam kelas. Penguatan pendidikan karakter juga dilakukan setelah para santri masuk asrama untuk kemudian mempelajari kurikulum pesantren. Dalam kegiatan ini santri tidak hanya ditanamkan nilai-nilai karakter melainkan juga akhlakul karimah atau sifat-sifat terpuji, seperti cinta kepada Allah, berbakti kepada orangtua, sopan santun, tolong menolong dan lain-lain. Metode yang digunakan dalam penanaman nilai-nilai karakter dan akhlakul kharimahini ini, antara lain berupa metode suri tauladan, penyampain kisah-kisah atau cerita, pembiasaan, disiplin, ceramah, kedisiplinan, serta hukuman dan penghargaan (reward and punishment).

Dari penjelasan tersebut setidaknya ada tiga poin penting yang harus ditekankan dalam kegiatan pembelajaran. Hal tersebut sebagaimana dikemukakan Nugraha (2019), antara lain: 1) pendekatan terhadap isi materi pembelajaran, 2) pendekatan terhadap proses pembelajaran dan 3) pendekatan terhadap pencapaian pengetahuan yang didapat setelah mengikuti proses pembelajaran. Melalui tiga pendekatan tersebut maka, akan terjadi proses belajar pada peserta didik untuk mengetahui (knowing) suatu konsep nilai yang pada awalnya dianggap asing atau abstrak ke bentuk perbuatan belajar untuk melakukan (doing) atau mengerjakan (working) sesuatu. Misalnya saja untuk nilai keikhlasan berkorban pada diri pahlawan yang kemudian diimplementasikan dengan cara mengajarkan kepada peserta didik untuk bersedia menyumbangkan uang atau barang berharga agar diberikan kepada mereka yang sedang mengalami musibah ataupun bencana alam. Berbagai kegiatan dan metode yang dilakukan pondok pesantren Darul Ulum semata-mata dalam rangka menyiapkan lulusan atau alumni pesantren yang bertaqwa, berilmu, cerdas dan berakhlakul karimah Karena, aktivitas pendidikan pesantren dalam beragama baik qalbiyah (jiwa) maupun badaniyyah (raga) - qauliyah (perkataan) maupun perbuatan fi'liyah, tidak akan bernilai sama sekali jika tidak dibalut dengan kebagusan karakter dan keterpujian akhlak.

Dari paparan penjelasan yang telah dikemukakan, maka pendidikan karakter yang dilakukan di pondok pesantren Darul Ulum dapat dikatakan jauh lebih baik jika dibandingkan dengan implementasi pendidikan karakter yang ada di sekolah biasa. Hal ini didasarkan pada ketersediaan waktu belajar yang jauh lebih lama, sistem pengawasan terhadap santri yang bersifat komprehensif, serta lingkungan pesantren yang religius dan mendukung terjadinya terinternalisasinya pendidikan 
karakter antara yang diperoleh dalam kegiatan pembelajaran dengan realitasnya dalam kehidupan sehari-hari. Oleh karena itu, pendidikan pesantren dapat dikatakan sebagai tempat penanaman pendidikan karakter yang ideal.

\section{SIMPULAN DAN SARAN \\ Simpulan}

Berdasarkan pembahasan hasil penelitian, maka dapat diketahui bahwa pondok pesantren Darul Ulum Kubu Raya telah melaksanakan Penguatan Pendidikan Karakter di (PPK) melalui kegiatan intrakurikuler, kokurikuler dan ekstrakurikuler. Adapun nilai-nilai nilai-nilai karakter yang diterapkan dalam kegiatan pembelajarannya antara lain:1) religius, 2) jujur, 3) toleransi, 4) disiplin, 5) kerja keras, 6) kreatif, 7) mandiri, 8) demokratis, 9) rasa ingin tahu, 10) semangat kebersamaan, 11) cinta tanah air, 12) menghargai prestasi, 13) bersahabat atau komunikatif, 14) cinta damai, 15) gemar membaca, 16) peduli lingkungan, 17) peduli sosial, dan 18) tanggungjawab. Selain itu, tidak hanya dalam kegiatan pendidikan formal. penguatan pendidikan karakter juga dilakukan di asrama melalui metode suri tauladan, penyampain kisah-kisah atau cerita, pembiasaan, disiplin, ceramah, kedisiplinan serta hukuman dan penghargaan (reward and punishment).

\section{Saran}

Saran peneliti terhadap Penguatan Pendidikan Karakter (PPK) di pondok pesantren darul ulum Kabupaten Kubu Raya adalah kegiatan ini hendaknya dikembangkan dengan bekerjasama secara independen baik internal dan eksternal, termasuk dalam kegiatan penilaiannya dilakukan secara komprehensif dan tidak terpisah antara penilaian PPK dalam kelas maupun ketika santri berada di lingkungn pesantren.

\section{DAFTAR RUJUKAN}

Citra, Y. (2012). Pelaksanaan pendidikan karakter dalam pembelajaran. Jurnal Ilmiah Pendidikan Khusus, 1(1), 237-249.

Fauzan, F. (2017). Urgensi Kurikulum Integrasi di Pondok Pesantren dalam Membentuk Manusia Berkualitas. Fikrotuna, 6(2).

Keputusan Menteri Agama Republik Indonesia Nomor 117 tahun 2014 tentang Implementasi Kurikulum 2013 di Madrasah.

Khoiriyah, R., Imron, A., Munif, A., \& Munawaroh, L. (2018). Penguatan Kampung Santri untuk Pengembangan Masyarakat Sadar Hukum di Wilayah Mangkang Kota Semarang. Dimas: Jurnal Pemikiran Agama untuk Pemberdayaan, 17(2), 253-276.

Krisdiyanto, G., Muflikha, M., Sahara, E. E., \& Mahfud, C. (2019). Sistem Pendidikan Pesantren dan Tantangan Modernitas. Tarbawi: Jurnal Ilmu Pendidikan, 15(1), 11-21.

Nashihin, H. (2017). Pendidikan Karakter Berbasis Budaya Pesantren. Semarang: CV. Pilar Nusantara Semarang.

Nugraha, M. T. (2019). Rekonsiliasi nilai-nilai kepahlawanan serta internalisasinya dalam pendidikan Islam. Ta'dibuna: Jurnal Pendidikan Islam, 8(2), 241-258.

Nugraha, M.T. (2019). Sejarah Pendidikan Islam: Memahami Kemajuan Peradaban Islam Klasik hingga Modern. Yogyakarta: Diandra.

Nugraha, T. (2015). Revitalisasi Pendidikan Akhlak Mulia dalam Pembentukan Karakter Mahasiswa di Perguruan Tinggi Agama Islam. Raheema: Jurnal Studi Gender dan Anak, 2(2). 
170 Instructional Development Journal (IDJ), Vol. 3, No. 3, Desember 2020, Hal. 163-170

Peraturan Menteri Pendidikan dan Kebudayaan Republik Indonesia Nomor 20 Tahun 2018 Tentang Penguatan Pendidikan Karakter Pada Satuan Pendidikan Formal.

Peraturan Menteri Pendidikan dan Kebudayaan Republik Indonesia Nomor 20 Tahun 2018 Tentang Penguatan Pendidikan Karakter Pada Satuan Pendidikan Formal.

Peraturan Presiden Republik Indonesia nomor 8 tahun 2012 tentang Kerangka Kualifikasi Nasional Indonesia.

Qomar, M. (2007). Pesantren: Dari Transformasi Metodologi Menuju Demokratisasi Institusi. Jakarta: Penerbit Erlangga.

Samsudin, S. (2020, February). Tantangan Lembaga Pendidikan Pesantren di Era Disrupsi. In Conference on Islamic Studies FAI 2019 (pp. 221-230).

Sukiyat. (2020). Strategi Implementasi Pendidikan Karakter. Surabaya: CV. Jakad Media Publishing.

Syahara, R. (2001). Krisis Moral dan Krisis Identitas: Kendala dalam Menghadapi Tantangan Globalisasi.Simposium dan Lokakarya Internasional II: Globalisasi dan Kebudayaan Lokal: Suatu Dialektika Menuju Indonesia Baru. Padang: Universitas Andalas.

Undang-Undang Republik Indonesia Nomor 18 Tahun 2019 tentang Pesantren. 